\title{
Screening potomků osob s časnou manifestací ICHS - editorial
}

\author{
Jan Bruthans \\ Centrum kardiovaskulární prevence 1. LF UK a Thomayerovy nemocnice, Praha

\begin{abstract}
Komentář k | Editorial on
Mateřánková $\mathrm{M}$ et al. Rizikové faktory kardiovaskulárních onemocnění u potomků nemocných po časném infarktu myokardu. Vnitř Lék 2017; 63(6): 398-402.
\end{abstract}

V tomto čísle publikovaná práce Mateřánková M et al Rizikové faktory kardiovaskulárních onemocnění u potomků nemocných po časném infarktu myokardu se věnuje zásadnímu problému. Rizikové faktory kardiovaskulárních (KV) onemocnění aterosklerotického původu co do prevalence i co do tíže výrazně narůstají s věkem stejně jako nemocnost a úmrtnost na tato KV onemocnění. Pokud by se zdařilo nárůst $\mathrm{KV}$ rizikových faktorů s věkem brzdit či dokonce eliminovat, Ize oprávněně předpokládat, že by se stoupajícím věkem progredovala nemocnost a úmrtnost na KV onemocnění podstatně méně. Nelze ovšem pominout genetické faktory predispozice ke KV onemocněním - zde je profylaxe podstatně složitější.

Publikovaná práce zjištovala, kdy se zvýšené kardiovaskulární riziko u potomků nemocných po časném infarktu myokardu objevuje a kdy je tedy racionální ho intervenovat. Nikoliv překvapivě a v souhlasu s předchozími studiemi [1-5] nachází u potomků nemocných s časnými projevy ICHS proti kontrolní populaci vyšší prevalenci KV rizikových faktorů, a to jak základních rizikových faktorů (RF): vyšší krevní tlak, vyšší prevalenci hypertenze, vyšší LDL-cholesterol a triglyceridemii, tak faktorů přímo spojených se špatným životním stylem: kouření, vyšší hmotnost i vyšší prevalenci zvýšené glykemie nalačno, a to již v mladším věku (průměrný věk v souboru potomků byl 28,7 roku). Práce nachází ve skupině potomků oproti kontrolní skupině zvýšenou tepennou tuhost aorty, obdobně starší práce nalezly ve skupině potomků cévní postižení a zvýšenou tloušt'ku intima-media karotid [6,7]. Také vypočtené celkové KV riziko podle systému SCORE bylo ve skupině potomků oproti kontrolní skupině vyšší.

Další dříve publikované práce dokumentují zvýšenou morbiditu a mortalitu na KV onemocnění u potomků pacientů s prokázanou ICHS. Vyšší riziko představuje anamnéza matek než otců, riziko dále výrazně narůstá při výskytu ICHS u více členů rodiny. K manifestaci KV onemocnění dochází dříve než u osob bez rodinné zátěže. Relativní podíl genetické predispozice a sdíleného životního stylu nelze však přesně stanovit a zřejmě se v jednotlivých rodinách liší [8-12].
Řada kardiovaskulárních guidelines doporučuje screening potomků pacientů s předčasným KV onemocněním, zejména pacientů s časným infarktem [13]. Tento postup je postupem primární prevence u osob s vysokým rizikem. (V rámci KV prevence lze definovat 3 modely: primární populační, primární u vysoce rizikových osob a sekundární prevenci). Screening potomků osob s předčasným KV onemocněním (ICHS prokázána u mužư před 55., u žen před 60. rokem věku; tato studie zvolila kritérium AIM před 50. rokem věku) má proti víceméně nahodilému vyhledávání osob s vysokým rizikem (anamnéza, komorbidity, laboratorní hodnoty atd) několik výhod. Rodinní přislušníci jsou zpravidla alarmováni víceméně nečekanou př́hodou v rodině, a jsou tedy více nakloněni spolupráci s lékaři, mají i lepší komplianci. Osoby propouštěné z nemocnice po časném AIM apod by měly být upozorněny na potřebu screeningového vyšetření potomků, popřípadě i sourozenců a partnerů. V tomto vzorku populace, jak dokládá i publikovaná práce, Ize očekávat vyšší kardiovaskulární riziko i vyšší riziko kardiovaskulárních příhod včetně fatálních (minimálně dvojnásobné proti ostatní populaci). Kontrola rizikových faktorů a další kardiologická léčba by mohla dále snížit prevalenci AIM a další KV morbiditu a mortalitu [8].

Problematika časného AIM je ovšem širší, vedle základních rizikových faktorů, zejména kouření, familiární hypercholesterolemie a prokoagulačních stavů jsou to další, relativně vzácnější nozologické entity, např. strukturální onemocnění tepen (svalové můstky a anomální odstupy koronárních tepen), zánětlivá onemocnění cévní stěny (Kawasakiho choroba a další), systémová onemocnění pojiva, malignity, užívání omamných psychotropních látek, z nichž některé mají vazokonstrikční účinky (kokain a u nás také pervitin), antifosfolipidemický syndrom a další, po kterých je třeba cíleně pátrat [14].

Navzdory doporučením se screening potomků osob s časnou manifestací ICHS nedaří, tato cílová skupina je oslovována minimálně $[3,8,15,16]$. Pokud jsou osloveni, je další prevence méně úspěšná v důsledku nižší kompliance, zejména u nižších sociálních/méně edukovaných vrstev [17]. 
Se znalostí zvýšeného rizikového profilu (dokumentovala to i publikovaná studie) a horší prognózy potomků osob s časnou manifestací ICHS je v této subpopulaci jednoznačně indikována cílená režimová a eventuálně i medikamentózní primárně preventivní péče jako nákladově efektivní a racionální postup. Další péče o tyto pacienty se odvijí od rádně vyhodnocené a uzavřené hospitalizace pacienta s časnou manifestací ICHS.

\section{Literatura}

1. Vulic D, Loncar S, Ostojic M et al. Risk factor indicators in offspring of patients with premature coronary heart disease in Banja Luka region/Republic Srpska/Bosnia and Hercegovina. Arch Med Sci 2016; 12(4): 736-741. Dostupné z DOI: <http://dx.doi.org/10.5114/ aoms.2016.60958>

2. Allen JK, Blumenthal RS. Risk factors in the offspring of women with premature coronary heart disease. Am Heart J 1998; 135(3): 428-434.

3. De Sutter J, De Bacquer D, Kotseva K et al. Screening of family members of patients with premature coronary heart disease. Results from the EUROASPIRE II family survey. Eur Heart J 2003; 24(3): 249-257.

4. Bao W, Srinivisan SR, Wattigney WA et al. The relation of parental cardiovascular disease to risk factors in children and young adults: the Bogalusa Heart Study. Circulation 1995; 91(2):365-371.

5. Widhalm K, Koch S, Pakosta R et al. Serum lipids, lipoproteins and apolipoproteins in children with and without familial history of premature coronary heart disease. J Am Coll Nutr 1992; 11(Suppl): 32S-35S.

6. Gaeta G, De Michele M, Cuomo $S$ et al. Arterial abnormalities in the offspring of patients with premature myocardial infarction. $\mathrm{N}$ Engl J Med 2000; 343(12): 840-846.

7. Cuomo S, Guarini P, Gaeta G et al. Increased carotid intima-media thickness in children-adolescents, and young adults with a parental history of premature myocardial infarction. Eur Heart J 2002; 23(17): 1345-1350.

8. Chow $\mathrm{CK}$, Pell CH, Walker A et al. Families of patients with premature coronary heart disease. BMJ 2007; 335(7618): 481-485.

9. ten Kate LP, Boman H, Daiger SP et al. Familial aggregation of coronary heart disease and its relation to known genetic risk factors. Am J Cardiol 1982; 50(5): 945-953.
10. Jousilahti P, Puska P, Vartiainen E et al. Parental history of premature coronary heart disease: an independent risk factor of myocardial infarction. J Clin Epidemiol 1996; 49(5): 497-503.

11. Myers RH, Kiely DK, Cupless LA et al. Parental history is an independent risk factor for coronary heart disease: the Framingham Study. Am Heart J 1990; 120(4): 963-969.

12. Leander K, Hallquist J, Reuterwall C et al. Family history of coronary heart disease, a strong risk factor for myocardial infarction interacting with other cardiovascular risk factors: results from the Stockholm heart epidemiology program (SHEEP). Epidemiology 2001; 12(2): 215-221.

13. Perk J, De Backer G, Gohlke H et al. European Guidelines on cardiovascular disease prevention in clinical practice (version 2012): The Fifth Joint Task Force of the European Society of Cardiology and Other Societies on cardiovascular Disease Prevention in Clinical Practice (constituted by representatives of nine societes and by invited experts). Atherosclerosis 2012; 223(1): 1-68. Dostupné z DOI: <http://dx.doi.org/10.1016/j.atherosclerosis.2012.05.007>.

14. Linhart A, Dostálová $G$, Bělohlávek J et al. Patogeneze a príčiny vzniku akutního infarktu myokardu u mladých nemocných. Postgraduální medicína 2012; 14(Suppl 4): S8-S11.

15. Hengstenberg C, Holmer SR, Mayer B et al. Siblings of myocardial infarction patients are overlooked in primary prevention of cardiovascular disease. Eur Heart J 2001; 22(11): 926-933.

16. Swanson JR, Pearson TA. Screening family members at high risk for coronary disease. Why isn't it done? Am J Prev Med 2001; 20(1): 50-55.

17. Bruthans J, Mayer jr. O, De Bacquer D et al. Educational level and risk control in patients with established coronary heart disease. Eur J Prev Cardiol 2016; 23(8): 881-890. Dostupné z DOI: <http://dx.doi. org/10.1177/2047487315601078>

\section{doc. MUDr. Jan Bruthans, CSc., FESC $\triangle$ jan.bruthans@seznam.cz}

Centrum kardiovaskulární prevence 1. LF UK a Thomayerovy nemocnice, Praha

www.ftn.cz

Doručeno do redakce 13. 6. 2017 